\title{
Cyclicality of Lending Behavior by Banking Sector for the Period (2000-2013): Evidence from Jordan
}

\author{
Qais A. Al-Kilani ${ }^{1} \&$ Thair A. Kaddumi ${ }^{1}$ \\ ${ }^{1}$ Finance and Banking Science Department, Applied Science Private University, Amman, Jordan \\ Correspondence: Thair A. Kaddumi, Finance and Banking Science Department, Applied Science Private \\ University, P.O. Box 166, Postal Code 11931, Amman, Jordan. Tel: 962-795-004-334. E-mail: \\ thair_lion@asu.edu.jo or lion_kanoosh@yahoo.com
}

Received: January 12, 2015

Accepted: January 19, 2015

Online Published: March 25, 2015

doi:10.5539/ijef.v7n4p57

URL: http://dx.doi.org/10.5539/ijef.v7n4p57

\begin{abstract}
All economic sectors and individuals in Jordan rely mainly on banks to cover their shortage in money, thus banking sector plays a vital role in enhancing investments and economic development by standing in the middle between deficit units and surplus units. The major goal of this study is to identify what are the main drivers that impact lending behavior in Jordan. Using panel data and applying multi regression analysis on (13) Jordanian Conventional banks and two Islamic banks for the period (2000-2013) that are covered in this research, we found that lending behavior is statistically significantly affected by internal factors (DV, IR and net profit after tax) and it is also affected significantly by external factor (RR, GDP, IFR, OWDR and Red. R). Also the analysis indicated that OWDR and Red. R as a proxy for monetary policy did have a negative impact on lending behavior but not significantly proven. The study also reached to a conclusion that the amount of loans and advances extended by Jordanian banks is not affected by rate of interest. We recommend that Jordanian banks' management should take into consideration internal specific factors as well as external specific factor with more care while formulating their lending policy, moreover central bank in cooperation with the Jordanian banking sector should work in more productive relationship in order to enhance more the economic growth.
\end{abstract}

Keywords: lending behavior, monetary policy, banking sector, central bank

\section{Introduction}

Investment cycle momentum depends mainly on funds availability were commercial banks (CB) are the major players in this regard, as commercial banks are considered the backbone of country's financial system, as banks act as an intermediaries between different society units and the do so in order to generate returns. Many studies tried to investigate into the linkage between the financial system and investment cycle. Banks working in emerging economies do not have enough capability to provide long-term financial needs to private organizations that is required for investments' augmentation. In some other words, financial barriers of local banks in emerging markets lead to low level of investment and constrain lending to borrowers (Tomak, 2013). Moreover in developing countries, bank's lending behavior significantly will have a potential impact on executing the monetary policy than in developed countries. Generally speaking bank's loans are one of the most important sources of long-term financing in most countries (Freixas \& Rochet, 2008).

Since the early emergence of money, there was always two different units - those who own surplus money (surplus units) and those who are in need of such surplus money (deficit units). Thus one of the main drivers that led to the existence of financial credit system was to find a mean that these two units should meet to fulfill the other party requirement. It started with direct financing between both surplus unit and deficit units (Akpaniko \& Acha, 2010). But were the need aroused to find away to collect all these surplus money from different sources (individuals or legal entities) so that they will be able to grant funds to deficit units (indirect lending). Thus Commercial banks are the main provider of such type of service in order to extend credit to business units and keeps the economic cycle moving (Mckinon, 2005).

Many Studies have investigated behind the variables that are responsible in determining banks' lending behavior. This study do differ from these studies will focus on investigating into the internal factors (Deposit Volume - DV, Interest Rate - IR and Net Profit after Tax) and the external factors (Reserve Requirements - RR, Gross Domestic product-GDP, Inflation Rate - IFR, Overnight Window Deposit Rate - OWDR and Rediscount Rate - 
Red. R) That influence baking sector lending behavior in Jordan.

\section{Literature Preview}

(Slovin \& Sushka, 1983) investigated into the commercial banks loans' level determinants rates, as they argued for the independence of liability: assets management policy, supported by experimental evidence based on time series data.

(Tomak, 2013), study was based on private commercial banks and government owned banks taking into account bank based determinants such as bank size and funds availability and market based factors such as rate of interest, GDP and inflation rate. The study concluded that the major factors that affect commercial banks lending behavior are bank's size, total liabilities and rate of inflation, more over the study indicated that commercial banks performance outperformed Government owned banks.

(Toni, 2008) studied profitability macroeconomic factors that influence banks' lending determinants in Nigeria, The study reached to a number of number of results one of the most important one was that macroeconomic factors such as rate of inflation, rate of interest, monetary policy and rate of exchange are the main determinants of banks' profitability level. (Talavera at el., 2006) pointed that the lending level by banks will grow during boom periods and less level of macroeconomics instability and will decline during recession periods.

(Chernykh \& Theodossiou, 2011), run their research on a sample of Russian banks, were they found that banks ability to grant more loans depends on factors such as: market capitalization, bank size and the availability of long term liabilities and that banks with low capital level, provide a low level of long term finance.

(Adofu \& Audu, 2010) to test the influence of interest deregulation on increasing the agricultural productivity by adopting ordinary least square model. The researchers found that rate of interest own a substantial role in mobilizing and developing economic activities. (Rasheed, 2010) by applying the error correction model they concluded that the more the Nigerian financial system incorporate more with the international market, the foreign investments will play a major role in fixing the local rate of interest.

Olumuyiwa at el. (2012) in their study they investigated into lending behavior and the level of lending in Nigerian commercial banks, they found that there is a direct relationship between deposit volume and loans and advances volume, from the other side factors such as naira rate of foreign exchange, GDP and reserve requirement by central bank do reflect a negative relationship with lending behavior.

Drumond and Jorge (2013) theoretically tested the effect of banking sector structure on lending behavior in the context of a new regulatory environment. They indicated that shifting from risk free capital requirements to risky ones the rate of interest on lending. While (Felicia, 2011) applied regression analysis to study commercial banks lending behavior's determinants, were he pointed out that the main determinant that effect the Nigerian lending behavior was the deposit volume. (Amidu, 2006) investigated if the Ghanaian banks lending behavior is limited due to monetary policy, using panel cross sectional data analysis, found that lending behavior by Ghanaian commercial banks are significantly affected by change in the volume of money supply and economic activities, more over the prime rate and the rate of inflation do have an adverse effect on commercial banks lending behavior. This is the same result reached by (Bernanke \& Blinder, 1988) that monetary policy is the main factor that constrain commercial banks lending behavior. While (Pausch \& Welzel, 2002) analyzed the role capital adequacy standard by applying Klien-Monti model, as they concluded that adoption of capital adequacy standard may cause an increase in lending rate for one time but it also indicated that such standard will have no effect on deposit rate.

Ogbokor and Moses (2014) study which was conducted on Namibia (1993-2002), found that demand on banks' loan is influenced more by other factors rather than by rate of interest such as REPO rate by central bank that could be used an effective way to direct credit by banks.

In a study by (Guo \& Stepanyan, 2011) they revealed that foreign and domestic and foreign financing are positively related with credit growth, as the stronger is the economic growth means a growth in credit volume while inflation rate affect adversely the credit growth.

\section{Theoretical Framework}

\subsection{Banking Sector in Jordan}

Jordanian Banking industry plays a significant role as the main financial lender to individual as well as business organization and plays a leading role in economic activities (World Bank, 2003). At present there are 26 banks working in Jordan (10 banks are Non- Jordanian banks constitute almost $12 \%$ of the total banking sector assets) out of it 15 commercial and Islamic banks are listed in Amman Stock Exchange (Banking Sector Report, 2013), 
all are working under the umbrella of the Jordanian Central Bank (CBJ) which was established in 1964, which was in charge of applying monetary policy and controlling the volume of liquidity within the economy through direct methods (rediscount rate, legal reserve requirements and credit limits) tell early 1990's, then since 1993 it started adopting indirect methods such as (open market operation, Certificate of deposit and overnight deposit) for the same aforementioned purposes. Since 1989, the Central Bank of Jordan (CBJ) has introduced a number of reforms' measures to create a secured and competitive. Such reforms included increasing the paid-up capital and relaxing all the restrictions on the movement of trade in foreign currency in 1997 (JIB, 2005). More reforms' measures were also initiated certain measures to develop the sector during the period 1999-2002 (Zeitun, 2013). Such measures and procedures are adopted by central bank to ensure a sound and stable banking sector.

Banking sector in Jordan witnessed a development in all aspects for instance the amount of credit facilities in Jordan increases significantly, as at the end of financial year 2000 the total amount of credit amounted to J.D. 8,045 billion ( $\$ 11,343$ billion), and at the end of 2013 the total amount of credit facilities provided by banks amounted to J.D 24,341 billion ( $\$ 34,320$ billion, the below table shows the growth of credit facilities during the last 10 years (billion US dollar):

Table 1. Credit facilities growth in Jordanian banking sector (2000-2013)

\begin{tabular}{lcccccccccccccc}
\hline Year & 2000 & 2001 & 2002 & 2003 & 2004 & 2005 & 2006 & 2007 & 2008 & 2009 & 2010 & 2011 & 2012 & 2013 \\
\hline $\begin{array}{l}\text { Credit facilities } \\
\text { \% of }\end{array}$ & 11.34 & 11.16 & 11.12 & 12.33 & 13.86 & 17.23 & 20.83 & 25.30 & 29.32 & 29.12 & 30.19 & 31.05 & 32.92 & 34.32 \\
$\begin{array}{l}\text { Non-Jordanian } \\
\text { Banks }\end{array}$ & 13.41 & 14.08 & 15.95 & 17.66 & 8.74 & 8.78 & 8.69 & 9.39 & 14.00 & 10.66 & 9.36 & 9.56 & 10.42 & 11.23 \\
\hline
\end{tabular}

Source: Amman stock Exchange - ASE.

Due to central bank role the banking sector in Jordan is characterized by sound financial position from all aspect and this due to rigid procedures and surveillance conducted by Jordanian Central Bank. For instance the non performing loans percentage in Jordan reached 8.3\% at the end of 2013 and this is below the international standards rates, moreover the capital adequacy ratio reached $18.6 \%$ end of 2012 which is higher than the limit fixed by the Central Banks which is $12 \%$ and by the Basel committee standard of $8 \%$. Moreover the average leverage ratio reached $6.7 \%$ at the end of 2013, also its liquidity ratio reached $39 \%$ and $36 \%$ end of 2012 and 2013 respectively. (Association of Jordanian Banks Report, 2013). In general deposits act as a stable source of finance for banks (Song \& Thakor, 2007). We should mention that banks in Jordan depends mainly on deposit as the main source of finance, table- 2 below reveal the percentage of deposit as to total assets (2000-2013):

Table 2. Percentage of banks' total deposits to total assets

\begin{tabular}{lcccccccccccccc}
\hline Year & 2000 & 2001 & 2002 & 2003 & 2004 & 2005 & 2006 & 2007 & 2008 & 2009 & 2010 & 2011 & 2012 & 2013 \\
\hline Credit & 84.8 & 81.2 & 80.9 & 80.4 & 79.6 & 77.2 & 72.2 & 72.5 & 73.6 & 73.8 & 81.6 & 75.1 & 71.8 & 65.0 \\
facilities & $\%$ & $\%$ & $\%$ & $\%$ & $\%$ & $\%$ & $\%$ & $\%$ & $\%$ & $\%$ & $\%$ & $\%$ & $\%$ & $\%$ \\
\hline
\end{tabular}

Source: Amman stock Exchange - ASE.

\subsection{Lending Determinants}

Lending behavior by banks is long debated by many researchers, where they navigated into the factors that affect lending behavior. (Gertler \& Gilchrist, 2003) and (Chowdhury at el., 2003) Studied the effect of monetary policy, (Bibow, 2000) stated that saving volume and cash balances do affect lending volume. While (Bernake, 2000) pointed out that lending is motivated by the Government. Also factors such as foreign ownership do also affect lending behavior in banking sector (De Haas \& Van Lelyveld, 2010), while a study by (Takats, 2010); (De Youngat el., 2005) found that demand and supply are the main derivers of banks' credit facility amount. Analyst and economist have long admitted that there are various usually active factors when it comes to the determinants of lending behavior by banks (Ogbokor, 2014) bank credits in modern economies.

The significance and importance of banks' lending behavior have been viewed in many lectures and studies. Most of these lectures studied banks' lending behavior determinants from two angels - the external factors and the internal factors. Internal factors can be extracted from the financial statement of accounts and the non-financial aspect of bank's management like number of branches and the branch size (Haron, 2004). 
Commercial banks are considered the most important mobilize and allocator of financial resources. Therefore this role makes them a significant landmark in economic development and growth. But we should mention that performing such rule in an efficient way is linked to many variables, some of these variables are attributed to bank's management goals (profitability and solvency) also variables such as deposits' volume, banks' portfolio composition, rules and regulations enacted by the central banks, The aforementioned variable are to be taken into account by the bank's management while formulating its lending policy and behavior.

\subsection{Objectives of the Study}

Banking sector plays a very crucial role in enhancement of economic activities and as a major mobilizer of funds from deficit units to surplus units. This significant role may be affected by various factors, that are may be attributed to the bank's financial position indicator or may be attributed to other factors that out of the banking sector control. The purpose of this study can be summarized in the following points (questions):

a) What are the major factors that affect banking sector lending behavior?

b) Is it internal, external or monetary policy that majorly affects the banking sector lending behavior?

c) Identifying the nature of effect that the study variables do impose on lending behavior by banking sector.

d) To establish a concept related to the role of central bank measures in influencing the lending behavior by Jordanian banks.

\section{Hypothesis of the Study}

The study will be based on the following three main hypotheses as follow:

$\mathbf{H}_{1}$ : Internal factors do significantly impact the banking sector lending behavior

$\mathbf{H}_{2}$ : External factors do significantly impact the banking sector lending behavior.

$\mathbf{H}_{3}$ : Monetary policy by Central bank does significantly impact the banking sector lending behavior.

\section{Research Methodology and Data Analysis}

This study differ from other previous studies as it takes into consideration the factors that may have an impact on lending behavior by banking sector in Jordan from three angels - (1) internal factors (Deposit Volume-DV, Interest Rate-IR and Net Profit after Tax, (2) external factors (Reserve Requirements-RR, Gross Domestic product-GDP, Inflation Rate-IFR, Overnight Window Deposit Rate-OWDR and Rediscount Rate-Red. R) (3) monetary policy effect (OWDR and Red. R as a proxy for monetary policy. In order to investigate into the impact of the aforementioned factor on lending behavior, accumulated data of the banking sector were extracted for the period plus data related to external factors for the period (2000-2013) will be used for the purpose of testing the study hypothesis.

\subsection{Database and Statistical Approaches}

The data base of this research is an outcome of merged sources. First the amounts of loans (as a proxy for lending behavior), deposit volumes, net profit after tax, reserve requirement volumes are collected from the financial reports of Jordanian banks for the period (2000-2013), and GDP, interest rate, inflation rate, overnight window deposit rate and rediscount rate are also collected from the annual reports of the central bank of Jordan for the same period as illustrated in Appendix (A \&B)

Also the natural logarithm - LN for the amounts of loans as dependent variable and deposit volumes, net profit after tax, reserve requirement volumes and GDP as independent variables are calculated (as illustrated in Table 3). After that, using the panel data analysis, we run the Multi - Linear regression done for the independent and dependent variables in order to analyze the regression coefficients $(\beta \mathrm{s})$ between the loans as dependent variable and the internal, external and monetary policy factors as independent variables.

Table 3. Natural logarithm of variables

\begin{tabular}{ccccc}
\hline Loans & Deposit & Interest & Net profit after Tax & Reserve Requirements \\
\hline 22.81 & 23.63 & 21.07 & 18.86 & 20.91 \\
22.79 & 23.65 & 20.96 & 19.08 & 21.89 \\
22.79 & 23.66 & 20.73 & 18.98 & 22.00 \\
22.89 & 23.71 & 20.60 & 19.08 & 22.26 \\
23.01 & 23.82 & 20.67 & 19.47 & 22.31 \\
23.23 & 23.89 & 21.01 & 20.06 & 22.35 \\
\hline
\end{tabular}




\begin{tabular}{lllll}
\hline 23.42 & 23.95 & 21.31 & 20.15 & 22.30 \\
23.61 & 24.09 & 21.54 & 20.29 & 22.55 \\
23.76 & 24.19 & 21.57 & 20.36 & 22.58 \\
23.75 & 24.25 & 21.46 & 20.05 & 22.87 \\
23.79 & 24.40 & 21.40 & 19.96 & 22.93 \\
23.82 & 24.36 & 21.45 & 20.17 & 22.78 \\
23.87 & 24.34 & 21.57 & 20.25 & 22.66 \\
23.92 & 24.30 & 21.68 & 20.45 & 22.86 \\
\hline
\end{tabular}

Since the loan volumes of banks is a function of the independent variables, we can express this relationship by the following formula:

$$
Y=\alpha+\beta_{1}\left(X_{1}\right)+\beta_{2}\left(X_{2}\right)+\ldots .+\beta_{t}\left(X_{t}\right)+e
$$

\section{Where:}

Y: represents the dependent variable( loans - lending behavior);

$\alpha:$ is the constant of the regression formula;

$\boldsymbol{\beta}_{1}$ : is the regression coefficient of the first independent variable;

$\mathbf{X}_{1}$ : is the first independent variable;

$\boldsymbol{\beta}_{\mathrm{t}}$ :is the regression coefficient of the last independent variable;

$\mathbf{X}_{\mathbf{t}}$ : is the last independent variable;

e: is the standard error of the regression model.

\section{Empirical Results}

\subsection{Analyzing Impact of Internal Factors}

Table 4 presents the empirical results of the Multi regression analysis of pooled data using the independent variables:

Table 4. Presents the multi regression results: (R2) and (Sig) for independent variables

\begin{tabular}{lcc}
\hline Coefficient & $\mathrm{R}^{2}$ & $\mathrm{Sig}$ \\
\hline Internal Factors & 0.991 & 0.000 \\
External factors & 0.987 & 0.000 \\
Monetary Policy Factors & 0.203 & 0.287 \\
\hline
\end{tabular}

As indicated in table (4) above, and according to determinant value $\left(\mathrm{R}^{2}\right)$ the internal factors explain $99.1 \%$ of the changes in loans and advances amounts (lending behavior) granted by Jordanian banks and that the analysis also indicated a significant positive impact of internal factors (DV, IR and net profit after tax) on banks loans and advances, also the external factor RR, GDP, IFR, OWDR and Red. R together, do influence positively banks' lending behavior. But, monetary policy factors explain a positive impact amounted to $20.3 \%$ of the change in the amount of loans and advances, (Heuvel, 2005) study reached for the same result. The results also show that according to Sig - t. level, not all the internal factors have significant impact on loans and advances volume, only deposit volume and net profit after tax have positive significant impact for the period (2000-2013) at Sig $\leq 0.05$ while the interest rate has a positive impact on loans and advances but this impact is insignificant as shown in table 5 below. This insignificant positive impact may be due to inclusion of two Islamic banks in this research which do not deal with interest rate.

Table 5. Presents the multi regression results: (B) and (Sig) for internal independent variables

\begin{tabular}{lcc}
\hline Coefficient & $\mathrm{B}$ & Sig \\
\hline Deposit Volumes & 1.029 & 0.000 \\
Interest Rate & 0.040 & 0.071 \\
Net Profit After Tax & 0.331 & 0.000 \\
\hline
\end{tabular}




\subsection{Analyzing Impact of External Factors}

Table 5 above also shows that the external factors explain $98.7 \%$ of the change in the amount of loans and advances granted by Jordanian banking sector also the statistical analysis pointed out that there exist a positive impact of external factors (RR, GDP, IFR, OWDR and Red. R.) on banks loans and advances is found. In addition to the aforementioned, the Results show that according to Sig. level, not all the external factors have a significant impact on loans and advances, only the GDP has positive significant impact for the period (2000-2013) at Sig $\leq 0.05$ as shown in Table 4, same result was reached by a study conducted by (Panizza, 2004).

Table 6. Presents the multi regression results: (B) and (Sig) for external independent variables

\begin{tabular}{lcc}
\hline Coefficient & B & Sig \\
\hline Reserve requirement volumes & 0.130 & 0.161 \\
GDP & 0.764 & 0.000 \\
inflation rate & 0.003 & 0.691 \\
overnight windows deposit rate & 0.006 & 0.887 \\
rediscount rate & 0.055 & 0.144 \\
\hline
\end{tabular}

\section{Analyzing Impact of Monetary Policy}

Referring to Table 2 and to explain the impact of monetary policy factors on banks' lending behavior we can notice that these factors explain $20.3 \%$ of the change in the amount of loans and advances granted by Jordanian banks and such impact is statistically insignificant but indicates a negative impact as shown in Table 7. of these factors (overnight window deposit rate and rediscount rate) on banks loans and advances as sig-t value is more than $5 \%$ which is the level of significance approved for this study (Sig. $=27.8 \%$ ).

Table 7. Presents the multi regression results: (B) and (Sig) for monetary policy independent variables

\begin{tabular}{lcc}
\hline Coefficient & B & Sig \\
\hline overnight windows deposit rate & 0.309 & 0.123 \\
rediscount rate & -0.314 & 0.151 \\
\hline
\end{tabular}

\section{Conclusion}

Based on the above statistical analysis we should indicate that both the hypothesis $\left(\mathrm{H}_{1}\right.$ and $\left.\mathrm{H}_{2}\right)$ are accepted and that the internal factors and external factors do influence significantly and positively the lending behavior of Jordanian banks, while the monetary policy tools (OWDR and Red. R) were reflecting a negative but insignificant impact, nevertheless of the concept that central banks measures and tools are meant to direct the lending behavior of banks and this result is contradicting such notion as they have a mutual beneficiary relation between them, based on that we will reject hypothesis $\left(\mathrm{H}_{3}\right)$. Moreover its worth mentioning that the major determinants of Jordanian banks lending behavior was from internal factors which are under the control of banks management, were they should concentrate on to enhance their lending which ultimately will lead to increase in banks profitability, also they should act toward attracting more deposit, as its increase will lead to increase in loans and advances which is the major function of all banks. Moreover we should expose that interest rate has insignificant influence on lending behavior, this due to the fact that when borrowers (either individuals or legal entities) are in need of finance they will head to banks no matter how much is the interest rate, and also due to the inclusion of two Jordanian Islamic banks included in this research. Very important recommendation of this study, that commercial banks should be more responsive toward monetary policy procedures and tools, that aim at protecting the economy as well as the currency value.

\section{References}

Adofu, M. I., \& Audu, S. I. (2010). An Assessment of the Effect of Interest Rate Deregulation in Enhancing Agricultural Production in Nigeria. Current Research Journal of Economic Theory, 2(2), 82-86.

Akpanuko, \& Acha. (2010). Instability in the Banking industry: Is Dynamic Provisioning a leeway. The Nigeria Journal of Management Research, 5(i), 40-50.

Amidu, M. (2006). The Link Between Monetary Policy And Banks Lending Behavior: The Ghanaian Case. Banks and Bank Systems, 1(4), 38-48. 
Banking Sector Report. (2013). Jordan, 2nd Report, Oct. 2013.

Bernanke, B. S., \& Blinder, A. S. (1988). Credit, Money, and Aggregate Demand. American Economic Review, 435-439. http://dx.doi.org/10.3386/w2534

Bernanke, B. S., \& Blinder, A. S. (1992). The Federal Funds Rate and the Channels of Monetary Transmission. American Economic Review, 84(4), 901-921. http://dx.doi.org/10.3386/w3487

Bibow, J. (2000). The Loanable Funds Fallacy in Retrospect. History of Political Economy, 14(5), $789-831$. http://dx.doi.org/10.1215/00182702-32-4-789

Chernykh, L., \& Theodossiou, A. K. (2011). Determinants of Bank Long-term Lending Behavior: Evidence from Russia. Multinational Finance Journal, 15(3/4), 193-216.

Chowdhury, I., Hoffman, M., \& Schabert, A. (2003). Inflation Dynamics and the Cost channel of Monetary Transmission. European Economic Review, 995-1016. http://dx.doi.org/10.1016/j.euroecorev.2005.01.007

De Haas, R., \& Van Lelyveld, I. (2010). Internal Capital Markets and Lending By Multinational Bank Subsidiaries. Journal of Financial Intermediation, 19(1), 1-25. http://dx.doi.org/10.1016/j.jfi.2009.02.001

De Young, G., \& Winton. (2005). Risk Overhang and Loan Portfolio Decisions (pp. 1-34). Federal Reserve Bank of Chicago WP August (2005).

Drumond, I., \& Jorge, J. (2013). Loan Interest Rates Under Risk-Based Capital Requirements: The Impact of Banking Market Structure. Economic $\quad$ Modeling, $\quad 32$, http://dx.doi.org/10.1016/j.econmod.2013.02.017

Felicia, O. O. (2011). Determinants of Commercial Banks Lending Behavior in Nigeria. International Journal of Financial Research, 2(2), 1-12. http://dx.doi.org/10.5430/ijfr.v2n2p61

Freixas, X., \& Rochet, J. C. (2008). Microeconomics of Banking (2nd ed.). Massachusetts London, England: The MIT Press Cambridge.

Gertler, M., \& Gilchrist, S. (2003). The Role of Credit Market Imperfections in the Monetary Transmission Mechanism: Arguments and Evidence. Scandinavian Journal of Economics, 95(1), 43-64. http://dx.doi.org/10.2307/3440134

Guo, K., \& Stepanyan, V. (2011). Determinants of Bank Credit in Emerging Market Economies. IMF Working Paper WP/11/51.

Haron, S. (2004). Analysis of Financial Statement of commercial in Sweden (2nd ed., pp. 44-51). Melt world Publication.

Jordan Investment Bank (JIB). (2005). Finance and Banking. Retrieved from http://www.jordaninvestment.com/2c.htm

Mckinon, R. (2005). Money and Capital in Economic Development (1st ed., pp. 55-64). Banking Institution, Wahington DC. USA Publication.

Ogbokor, C. A., \& Moses, M. W. (2014). Investigating the Determinants of Commercial Banks Credit by the Business Sector In Namibia: A Co-Integration Analysis. Research Journal of Finance and Accounting, 5(8), 64-78.

Olumuyiwa, O. S., Oluwatosin, O. A., \& Chukwuemeka, O. E. (2012). Determinants of Lending Behaviour of Commercial Banks: Evidence From Nigeria, A Co-Integration Analysis (1975-2010). Journal of Humanities And Social Science, 5(5), 71-80. http://dx.doi.org/10.9790/0837-0557180

Panizza, F. (2004). A reform Without Losers: The Symbolic Economy of Civil Service Reform in Uruguay 1995-1996. Latin American Politics and Society, 46(3), 1-28. http://dx.doi.org/10.1111/j.1548-2456.2004.tb00283.x

Pausch, T., \& Welzel, P. (2002). Credit Risk and The Role of Capital Adequacy Regulation: Volkswirtschaftliche Diskussionsreihe. Institut für Volkswirtschaftslehre der Universitt Augsburg.

Rasheed, O. A. (2010). Interest rate determinants in Nigeria. International Research Journal of Finance and Economics, 2(3), 1-12. Retrieved from http://www.academicjournals.org/JEIF

Slovin, M. B., \& Sushka, M. E. (1983). A model of the Commercial Loan Rate. The Journal of Finance, 38(5), 1583-1596. http://dx.doi.org/10.1111/j.1540-6261.1983.tb03842.x 
Song, F., \& Thakor, A. V. (2007). Relationship Banking, Fragility, and the Asset-Liability Matching Problem. Review of Financial Studies, 20(6), 2129-2177. http://dx.doi.org/10.1093/rfs/hhm015

Takats, E. (2010). Was it Credit Supply? Cross-Border Bank Lending to Emerging Market Economies during the Financial Crisis. BIS Quarterly Review, 49-56.

Talavera, O., Tsapin, A., \& Zholud, O. (2006). Macroeconomic Uncertainty and Bank Lending: The Case of Ukraine. Economic System, 36(2), 279-293. http://dx.doi.org/10.1016/j.ecosys.2011.06.005

Tomak, S. (2013). Determinants of Commercial Banks' Lending Behavior: Evidence From Turkey. Asian Journal of Empirical Research, 3(8), 933-943.

Toni, U. (2008). Determinants of Bank profitability Macroeconomics, Evidence from Nigeria, Deakin University. Working paper. http://dx.doi.org/10.2139/ssrn.1231064

Van den, J. (2002). Does Bank Capital Matter for Monetary Policy Transmission. FRBNY Economic Policy Review, 259-261.

World Bank. (2003). The Hashemite Kingdom of Jordan Country Assistance Evaluation. Report No.26875-JO.

Zeitun, R., \& Benjelloun, H. (2013). The Efficiency of Banks and the Financial Crisis in a Developing Economy: The Case of Jordan. Journal of Finance, Accounting and Management, 4(1), 1-20.

\section{Appendix A. Independent Internal Factors}

\begin{tabular}{cccccc}
\hline \multirow{2}{*}{ Year } & \multicolumn{5}{c}{ Internal Factors } \\
\cline { 2 - 6 } 2000 & Loans & Deposit & Interest & Interest On Loans and advances & Net profit after Tax \\
\hline 2001 & $7,917,221,881$ & $18,648,219,517$ & $1,270,981,320$ & 11.38 & 11.88 \\
2002 & $7,888,802,962$ & $18,943,754,700$ & $1,005,606,613$ & 9.85 & $193,630,700$ \\
2003 & $8,745,531,757$ & $19,897,949,804$ & $886,913,788$ & 10.24 & $174,250,361$ \\
2004 & $9,825,907,557$ & $22,091,550,407$ & $945,451,100$ & 8.98 & $193,960,950$ \\
2005 & $12,216,907,211$ & $23,684,870,337$ & $1,329,970,719$ & 7.92 & $284,534,051$ \\
2006 & $14,772,271,394$ & $25,153,877,932$ & $1,802,038,477$ & 8.72 & $513,607,694$ \\
2007 & $17,937,734,412$ & $29,031,341,163$ & $2,259,250,977$ & 9.45 & $564,784,554$ \\
2008 & $20,792,617,320$ & $31,913,376,898$ & $2,324,914,250$ & 8.89 & $647,169,895$ \\
2009 & $20,651,660,614$ & $34,051,613,504$ & $2,085,413,947$ & 9.17 & $692,795,406$ \\
2010 & $21,408,367,027$ & $39,570,242,760$ & $1,975,240,695$ & 9.41 & $512,166,315$ \\
2011 & $22,020,352,390$ & $37,942,952,406$ & $2,067,969,464$ & 9.34 & $465,588,851$ \\
2012 & $23,367,007,166$ & $37,334,393,620$ & $2,331,054,011$ & 9.59 & $576,906,634$ \\
2013 & $24,341,154,121$ & $35,671,768,557$ & $2,599,784,251$ & 9.20 & $624,566,402$ \\
\hline
\end{tabular}

Appendix B. Independent External Factors and Monetary Policy Factors

\begin{tabular}{cccccc}
\hline \multirow{2}{*}{ Year } & \multicolumn{5}{c}{ Internal Factors } \\
\cline { 2 - 6 } & Reserve Requirements & GDP & Inflation Rate & Rediscount Rate & Overnight Window Deposit Rate \\
\hline 2000 & $1,208,593,343$ & $8,457,923,945$ & 0.70 & 6.50 & 5.75 \\
2001 & $3,220,252,574$ & $8,972,965,061$ & 1.80 & 5.00 & 3.88 \\
2002 & $3,595,913,156$ & $9,580,191,951$ & 1.80 & 4.50 & 2.2 \\
2003 & $4,664,499,207$ & $10,193,023,726$ & 1.60 & 2.50 & 2.00 \\
2004 & $4,866,384,268$ & $11,407,566,660$ & 2.60 & 3.75 & 2.25 \\
2005 & $5,080,968,070$ & $12,582,876,895$ & 3.50 & 6.50 & 4.50 \\
2006 & $4,860,118,305$ & $15,056,937,190$ & 6.25 & 7.50 & 5.25 \\
2007 & $6,195,797,150$ & $17,110,610,000$ & 4.70 & 7.00 & 4.75 \\
2008 & $6,393,158,278$ & $21,971,835,256$ & 13.90 & 6.25 & 4.00 \\
2009 & $8,563,375,488$ & $23,818,322,918$ & -0.70 & 4.75 & 2.50 \\
2010 & $9,104,219,608$ & $26,425,379,367$ & 5.00 & 4.25 & 2.00 \\
2011 & $7,789,978,339$ & $28,840,197,019$ & 4.40 & 4.50 & 2.25 \\
2012 & $6,940,390,081$ & $31,015,239,496$ & 4.70 & 5.00 & 4.00 \\
2013 & $8,476,522,184$ & $33,678,459,200$ & 5.60 & 5.25 & 3.75 \\
\hline
\end{tabular}

\section{Copyrights}

Copyright for this article is retained by the author(s), with first publication rights granted to the journal. 
This is an open-access article distributed under the terms and conditions of the Creative Commons Attribution license (http://creativecommons.org/licenses/by/3.0/). 